\title{
The seasonal distribution, diel vertical distribution and feeding behavior of Paraeuchaeta concinna in the shallow subtropical coastal waters of eastern Hong Kong
}

\author{
Chong Kim Wong ${ }^{*}$, Eva Y W Yau and Alle A Y Lie
}

\begin{abstract}
Background: Predatory copepods of the family Euchaetidae are widely distributed in polar, temperate, subtropical and tropical oceans. Paraeuchaeta concinna is the most abundant Euchaetidae in the subtropical coastal seas of Hong Kong and southern China. However, compared to Euchaetidae species in temperate and polar regions, relatively little information is available on the ecology of $P$. concinna and other Euchaetidae species in the subtropical oceans. This paper provides information on the seasonal abundance of $P$. concinna in the coastal seas of eastern Hong Kong. The diel vertical distribution of $P$. concinna, feeding behavior, and predation impact on mesozooplankton in eastern Hong Kong were also investigated.
\end{abstract}

Results: $P$. concinna is most abundant in winter and spring. Their abundance decreases shoreward, and densities are generally higher in the open waters of eastern Hong Kong than in the inner parts of Mirs Bay and Tolo Harbour. P. concinna exhibits both diel vertical migration and diel feeding rhythms in Mirs Bay. P. concinna females show strong preference for the copepods of the genera Acrocalanus, Paracalanus, and Parvocalanus, and remove $\sim 4 \%$ of their standing stocks daily.

Conclusions: The low abundance of $P$. concinna during most of the year suggests it is not indigenous to coastal seas of eastern Hong Kong. P. concinna performs diel vertical migration, most likely as a strategy to avoid visual predation. Gut content analysis showed that Acrocalanus, Paracalanus, and Parvocalanus are highly preferred prey of P. concinna. A daily predation impact of $\sim 4 \%$ of the standing stocks of Acrocalanus, Paracalanus, and Parvocalanus suggests that $P$. concinna may play an important role in regulating the populations of these small copepods in Mirs Bay, especially during winter and spring.

Keywords: Paraeuchaeta concinna, Seasonal distribution, Diel vertical migration, Feeding

\section{Background}

Marine calanoid copepods of the family Euchaetidae are widely distributed in polar, temperate, subtropical and tropical oceans, typically large in size $(2-12 \mathrm{~mm})$, and primarily predaceous [1]. Predation by Euchaetidae is known to significantly affect the abundance and distribution of mesozooplankton stocks in pelagic ecosystems [2-6]. Among Euchaetidae, the genera Paraeuchaeta and Euchaeta, which occur mainly in deep temperate and

\footnotetext{
* Correspondence: chongkimwong@cuhk.edu.hk

School of Life Sciences, The Chinese University of Hong Kong, Shatin, New Territories, Hong Kong SAR, China
}

arctic waters, have been studied extensively [7-14]. Various patterns of diel vertical migration (DVM), in which animals migrate to different depths of the water column in a daily cycle, have been reported in several species. In Paraeuchaeta norvegica, some populations exhibit strong DVM $[13,15]$, while others remain in deep waters throughout the day [16]. The vertical migratory behavior of carnivorous copepods is important as it can affect their diet, as well as the distribution of their prey and predators [7,17]. Compared to the large amount data from temperate and polar regions, information on the ecology of Euchaetidae species in tropical and 
subtropical coastal seas is scarce, despite their abundance and wide distribution $[18,19]$.

Euchaetidae is one of the most abundant groups of large predatory copepods in the coastal waters of Hong Kong and southern China [20-23]. In Hong Kong, four species of Euchaetidae, including Paraeuchaeta concinna (also known as Euchaeta concinna), Euchaeta indica, Paraeuchaeta plana (also known as Euchaeta plana), and Euchaeta rimana, have been reported, and their abundance is highest in oceanic waters in the east and southeast, where the influence of discharge from the Zhujiang River is low [20,24].

Tolo Harbour and Mirs Bay are two semi-enclosed bays in the northeastern part of Hong Kong. Tolo Harbour, a landlocked bay with an average depth of $12 \mathrm{~m}$, is connected to Mirs Bay by a narrow channel. Mirs Bay, a much larger bay with an average depth of $\sim 18 \mathrm{~m}$, is directly exposed to currents and waves from the open sea areas in the east and southeastern part of Hong Kong. Tolo Harbour has a copepod community of higher density and lower diversity compared to Mirs Bay [25]. The copepod communities in both bays are dominated by small copepods of the genera Paracalanus and Oithona, while larger copepods such as Subeucalanus subcrassus and Calanus sinicus are common only in the deeper waters outside Tolo Harbour [25,26]. Of the four species of Euchaetidae reported in Hong Kong, P. concinna is the most abundant [24]. This study aims to provide quantitative information on the seasonal distribution and feeding behavior of this predatory copepod in the coastal seas of eastern Hong Kong.

\section{Methods}

\section{Seasonal distribution}

Zooplankton samples were collected at intervals of two to three weeks at six fixed stations in the eastern part of Hong Kong over a two-year period from July 2003 to June 2005 (Figure 1). S1 (22 $\left.26^{\prime} 725^{\prime \prime N}, 114^{\circ} 14^{\prime} 566^{\prime E} \mathrm{E}\right)$ and S2 $\left(22^{\circ} 28^{\prime} 539^{\prime \prime} \mathrm{N}, 114^{\circ} 18^{\prime} 034^{\prime \prime E}\right)$ were located inside Tolo Harbour. S3 $\left(22^{\circ} 29^{\prime} 468^{\prime \prime} \mathrm{N}, 114^{\circ} 21^{\prime} 588^{\prime \prime} \mathrm{E}\right)$ was in the inner part of Mirs Bay, near the mouth of Tolo Harbour. S4 $\left(22^{\circ} 26^{\prime} 670^{\prime \prime} \mathrm{N}, 114^{\circ} 26^{\prime} 920^{\prime \prime} \mathrm{E}\right)$ was located in Mirs Bay. S5 $\left(22^{\circ} 17^{\prime} 560^{\prime \prime} \mathrm{N}, 114^{\circ} 26^{\prime} 920^{\prime \prime} \mathrm{E}\right)$ and S6 $\left(22^{\circ} 13^{\prime} 000^{\prime \prime} \mathrm{N}\right.$, $114^{\circ} 26^{\prime} 920^{\prime \prime E}$ ) were located outside Mirs Bay in the southeastern part of Hong Kong. Water depth increased from $\sim 20 \mathrm{~m}$ at S1 to $\sim 30 \mathrm{~m}$ at S6. Duplicate zooplankton samples were collected at each station by making vertical hauls from $2 \mathrm{~m}$ above the bottom to the surface with a conical plankton net $(0.5 \mathrm{~m}$ mouth diameter, 125 $\mu \mathrm{m}$ mesh size) and immediately preserved in $4 \%$ buffered formaldehyde solution. All samples were collected between 1000 and $1600 \mathrm{~h}$ to minimize diurnal variations in zooplankton abundance. Temperature and salinity were measured at the surface $(0.5 \mathrm{~m})$ of each station at the time of zooplankton sampling with a Hydrolab H20 water analysis system. In the laboratory, zooplankton samples were examined and enumerated under a stereomicroscope. P. concinna was identified according to Park [1].

\section{Diel patterns in vertical distribution and gut fullness}

The diel vertical distribution of $P$. concinna was studied at S5 $\left(22^{\circ} 17^{\prime} 560^{\prime \prime} \mathrm{N}, 114^{\circ} 26^{\prime} 920^{\prime \prime} \mathrm{E}\right)$ on 6-7 January 2005 (Figure 1). Sunrise and sunset times were $0700 \mathrm{~h}$ and $1800 \mathrm{~h}$, respectively. Duplicate zooplankton samples were taken from $0-5 \mathrm{~m}, 5-10 \mathrm{~m}, 10-15 \mathrm{~m}, 15-20 \mathrm{~m}$ and $20-25 \mathrm{~m}$ at $1200 \mathrm{~h}, 1600 \mathrm{~h}, 2000 \mathrm{~h}, 2400 \mathrm{~h}, 0400 \mathrm{~h}$ and $0800 \mathrm{~h}$ using a plankton net with a closing device ( $0.5 \mathrm{~m}$ mouth diameter, $125 \mu \mathrm{m}$ mesh size). All samples were immediately preserved in $4 \%$ buffered formaldehyde solution. Vertical profiles of temperature, salinity and DO were measured at noon and midnight with a Hydrolab H20 water analysis system. Light intensity was measured at noon only with a light meter (LI-250 light meter, LI-193SA underwater quantum sensor) and was expressed as the light refractive index, which represents the ratio of light intensity in the water to light intensity just above the surface.

In the laboratory, P. concinna was identified according to Park [1] and densities of adults were estimated by counting entire samples. Male and female $P$. concinna were identified according to the morphological characteristic of their reproductive structures. Females with (ovigerous) and without egg sac (non-ovigerous) were counted separately. Zooplankton densities were estimated by counting at least $5 \%$ of each sample. At least 100 copepods from each sample were identified to the genus level according to the descriptions of Zheng and Zhang [19] to provide information on species compositions.

The entire digestive tracts of 10 randomly sorted $P$. concinna adult females were dissected under a stereomicroscope according to the method of Øresland [9]. The stomach content in the anterior part of each digestive tract was examined under a light microscope and prey items were identified as far as possible to the lowest taxon, using identifiable structures such as the mandibles. The gut fullness index was estimated as the ratio of the volume of stomach content to the total volume of the stomach.

\section{Data analysis}

To compare the vertical distribution of the predator and prey, the weighted mean depth (WMD) was calculated using the equation of Worthington [27]:

$$
W M D=\left(\Sigma D_{i} d_{i}\right) / \Sigma D_{i}
$$

where $\mathrm{d}_{i}$ is the depth from which sample $i$ was collected, 


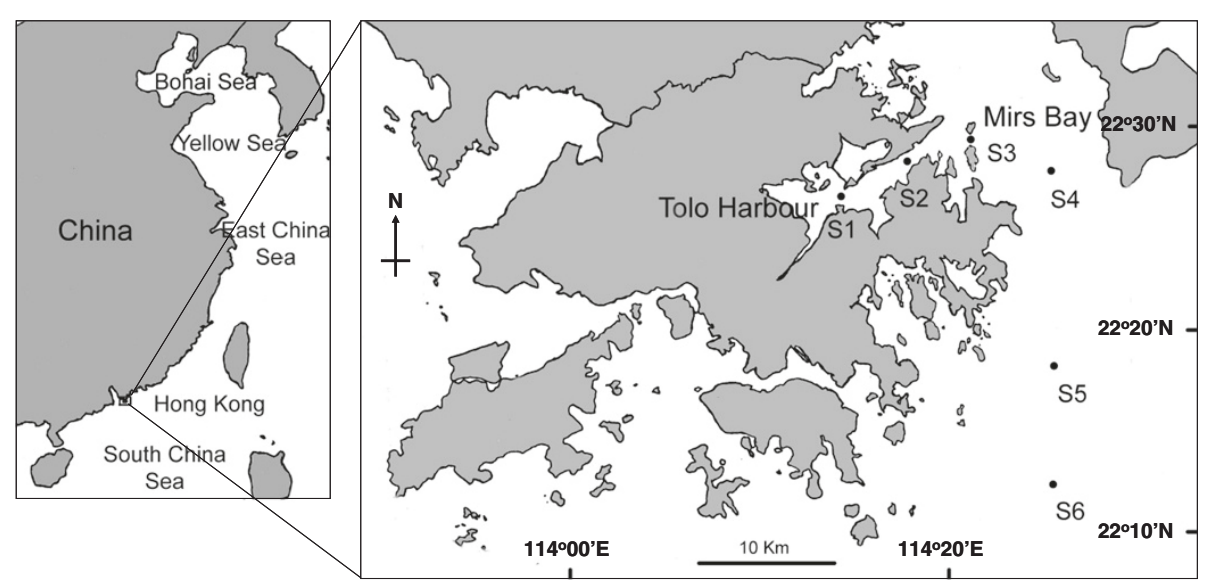

Figure 1 Map of Hong Kong showing the sampling stations in Tolo Harbour (S1, S2), Mirs Bay (S3, S4) and southeastern Hong Kong waters $(\mathrm{S} 5, \mathrm{S6})$.

and $\mathrm{D}_{i}$ is the density of P. concinna in sample $i$.

As Euchaetidae adult males, with their reduced mouthparts and intestines, do not feed [28,29], investigation of the feeding behavior of $P$. concinna was limited to the adult females.

Prey selectivity was calculated using the electivity measure $(\alpha)$ of Chesson [30]. Electivity for prey item $i$ $\left(\alpha_{i}\right)$ was calculated using the equation:

$$
\alpha_{i}=\left(r_{i} / p_{i}\right) /\left(\Sigma r_{i} / p_{i}\right)
$$

where $\mathrm{r}_{i}$ and $\mathrm{p}_{i}$ represent the proportion of prey item $i$ in the gut of the predator and in the water column, respectively. The measure $(\alpha)$ was converted to an electivity index $(\varepsilon)$ using the equation [31]:

$$
\varepsilon_{i}=\left(m \alpha_{i}-1\right) /\left[\left(m \alpha_{i}-2\right) \alpha_{i}+1\right]
$$

where $m$ is the number of prey items and the value of $\varepsilon$ ranges from -1 to +1 . Positive values indicate selection for and negative values indicate selection against the prey item.

The feeding rate $\left(\mathrm{I}_{t}\right)$ of $P$. concinna females for sampling time interval $t$, which was a duration of $4 \mathrm{~h}$, was estimated by the equation:

$$
I_{t}=4 G_{t} / k
$$

where $G_{t}$ is the number of prey per female for $P$. concinna collected at time interval $t$ and $k$ is the digestion time in hours.

The daily predation impact (PI) of female $P$. concinna on a particular prey was then estimated using the equation:

$$
P I=\Sigma\left[\left(I_{t} N_{t} / P_{t}\right) 100\right]
$$

where $\mathrm{I}_{t}$ is the feeding rate of female $P$. concinna at time interval $t . \mathrm{N}_{t}$ and $\mathrm{P}_{t}$ represent the densities of female $P$. concinna and prey at time interval $t$, respectively.

\section{Measurement of digestion time}

Digestion time, or the time required by $P$. concinna females to digest natural copepod prey, was determined in the laboratory. Live copepods were collected by vertical hauls at S5 and immediately returned to the laboratory in surface seawater in $10-\mathrm{L}$ plastic bottles. Adult females of $P$. concinna were sorted with wide-bore pipettes and maintained without food in $125 \mu \mathrm{m}$-filtered surface seawater at $20^{\circ} \mathrm{C}$ in large aquaria. After $24 \mathrm{~h}$, females that still swam actively were transferred individually to 1 -L fleakers. After an acclimation period of $\sim 1 \mathrm{~h}, 30$ small copepods were added to each fleaker as prey. Two groups of natural copepod prey, Paracalanus/ Parvocalanus and Acrocalanus, were used. Feeding activities of $P$. concinna was observed directly with a magnifying lens. To facilitate the observation of prey ingestion, prey were stained with neutral red for $\sim 30 \mathrm{~min}$ and washed with $125 \mu \mathrm{m}$ filtered seawater before being fed to $P$. concinna. Females that ingested a prey were immediately transferred to fleakers without prey and remained under constant observation. Digestion time was recorded as the duration between prey capture and egestion of a colored fecal pellet by the predator. The digestion times for each group of prey were obtained by observing 10 females.

\section{Statistical analysis}

Two criteria were used to detect the occurrence of diel vertical migration (DVM) in P. concinna and other copepods. Day-night differences in the WMD and percentage of population at the upper-most layer were compared using the Mann-Whitney rank sum test. Significant differences $(p<0.05)$ in both criteria indicated strong 
DVM, while a significant difference in only one criterion indicated weak DVM. No significant difference suggested that the animals did not exhibit DVM.

Gut fullness values were arcsine transformed and twoway ANOVA with Tukey multiple comparison was used to test for differences in the gut fullness of $P$. concinna females between day and night and among different depth layers.

\section{Results}

\section{Seasonal hydrography}

Surface temperature was higher in summer (June to September) than in winter (December to March) (Figure 2). Surface salinity was affected by seasonal patterns in precipitation, and was lower in spring and summer (April to September) than in autumn and winter (October to March).

\section{Seasonal abundance and spatial distribution}

The density of adult $P$. concinna was lowest at S1 in the inner part of Tolo Harbour and highest at S5 and S6 in the open seas of southeastern Hong Kong (Figure 3). Over the entire study period, average densities were $<0.1-0.4$ ind. $\mathrm{m}^{-3}$ at S1, S2 and S3, and 1.0-1.2 ind. $\mathrm{m}^{-3}$ at S4, S5 and S6. P. concinna was common only during winter and spring, and the highest densities were recorded in December and January. Density $>5$ ind. ${ }^{-3}$ appeared only when water temperature was $<21^{\circ} \mathrm{C}$ (Figure 4).

\section{Diel vertical distribution}

The diel pattern in the vertical distribution of $P$. concinna was studied at S5 on 6-7 January 2005. Averaged over the entire water column, the temperature was $17.6^{\circ} \mathrm{C}$ during the day and $17.3^{\circ} \mathrm{C}$ at night (Figure 5).

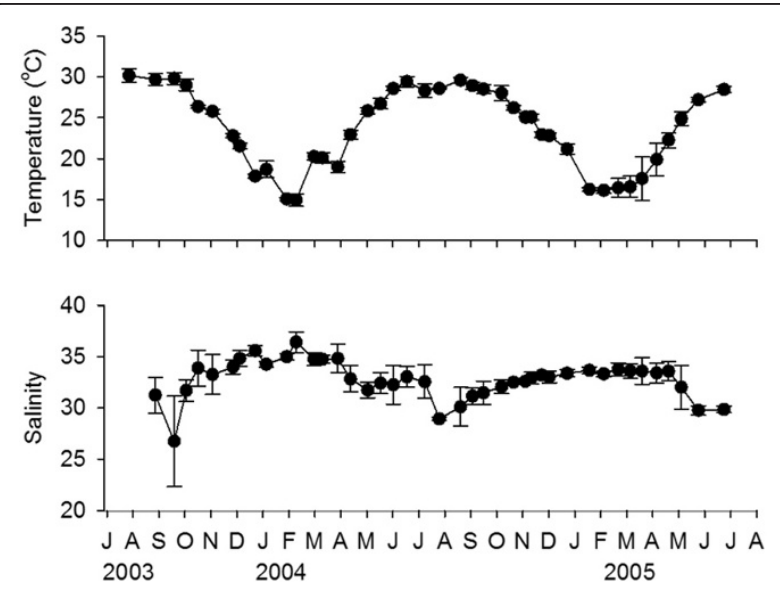

Figure 2 Seasonal variations in surface water temperature and salinity. Values are mean ( \pm Standard deviation) of the six sampling stations.
The difference in temperature between surface and $20 \mathrm{~m}$ was slight, and the water column was well oxygenated. Light intensity was measured at noon. The ratio of light intensity in the water to light intensity above the surface revealed that light attenuated rapidly in the upper $5 \mathrm{~m}$, and very little light reached depths below $15 \mathrm{~m}$ (Figure 5).

Most adult females stayed at depths below $10 \mathrm{~m}$ at noon and $1600 \mathrm{~h}$ (Figure 6). Upward migration between $1600 \mathrm{~h}$ and $2000 \mathrm{~h}$ was confirmed by an increase in density at $0-5 \mathrm{~m}$ from $<1$ ind. $\mathrm{m}^{-3}$ to $\sim 10$ ind. $\mathrm{m}^{-3}$. At midnight, the density at the upper-most layer was still $\sim 10$ ind. $\mathrm{m}^{-3}$, but most of the females had returned to depths below $15 \mathrm{~m}$. At $0800 \mathrm{~h}$ in the morning, almost no females were found at depths above $10 \mathrm{~m}$. The diel vertical distribution patterns displayed by both ovigerous and non-ovigerous females were similar to that observed in the entire female population. The vertical distribution of the males was also similar to that of the females. In conclusion, all P. concinna, including females (both ovigerous and non-ovigerous) and males, performed DVM, as both WMD and the percentage of the population at the surface showed significant differences between day and night $(p<0.05)$ (Table 1$)$.

\section{Feeding and predation impact}

$P$. concinna females tended to have empty guts during the day (Figure 7). Females with high gut fullness index first appeared at $2000 \mathrm{~h}$, and females with the highest gut fullness index were collected at midnight at 0-5 m. At $2000 \mathrm{~h}$, females collected in the upper $15 \mathrm{~m}$ of the water column had much higher gut fullness than females collected from the bottom. Females with high gut fullness index appeared in the bottom layers at midnight and $0400 \mathrm{~h}$. These observations suggested that P. concinna females fed at the surface layers and returned to deeper waters after feeding. Gut fullness decreased rapidly after midnight and returned to low levels at $0800 \mathrm{~h}$. Results of two-way ANOVA showed that the gut fullness of female $P$. concinna differed significantly between day and night $(p<0.001)$, but did not vary among the depth layers $(p>0.05)$.

Copepods, the major prey of female $P$. concinna, comprised $\sim 40 \%$ of the gut contents (Figure 8). Eggs, remains of crustaceans and unidentified items made up the remaining gut contents. All copepods found in the gut were calanoid copepods. Acrocalanus constituted $50 \%$ of all copepod prey. Other common copepod prey included Paracalanus/Parvocalanus ( 30\%) and copepodites of Canthocalanus ( 11\%). The electivity index ( $\varepsilon$ ) showed that Acrocalanus $(\varepsilon=0.51)$ and Paracalanus/ Parvocalanus $(\varepsilon=0.21)$ were the only prey items that were positively selected by female $P$. concinna. 

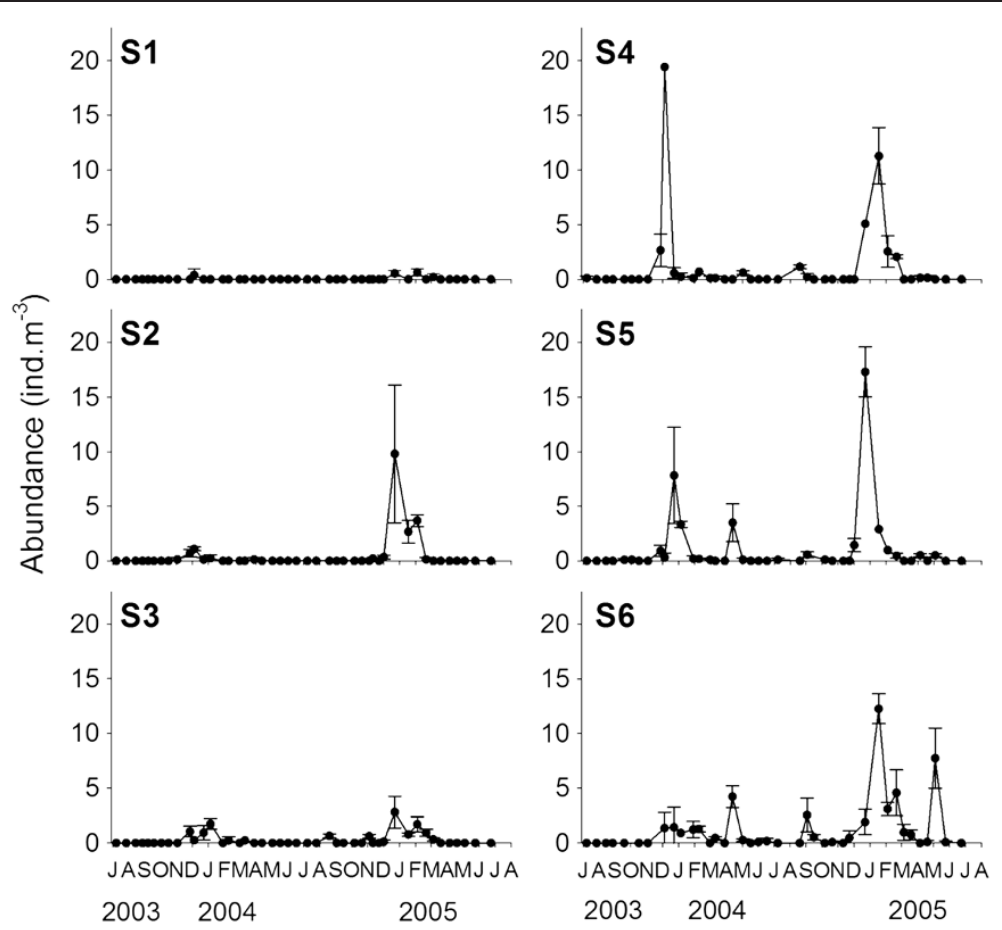

Figure 3 Temporal variation in the mean density ( \pm Standard deviation) of $P$. concinna in Tolo Harbour (S1 \& S2) and Mirs Bay (S3 \& S4) and southeastern Hong Kong waters (S5 \& S6).

The mean digestion times of female $P$. concinna were $5.3 \mathrm{~h}$ for Paracalanus/Parvocalanus and $5.6 \mathrm{~h}$ for Acrocalanus. The estimated feeding rates of female $P$. concinna ranged from 0 to 0.30 prey predator $^{-1} \mathrm{~h}^{-1}$ on Acrocalanus and 0 to 0.38 prey predator ${ }^{-1} \mathrm{~h}^{-1}$ on Paracalanus/Parvocalanus. Predation impact, expressed as the percentage of the standing stock removed daily by P. concinna, was $4.30 \%$ for Acrocalanus and $4.26 \%$ for Paracalanus/Parvocalanus.

\section{Prey availability}

Acrocalanus and Paracalanus/Parvocalanus, the most ingested and only positively selected prey of $P$. concinna

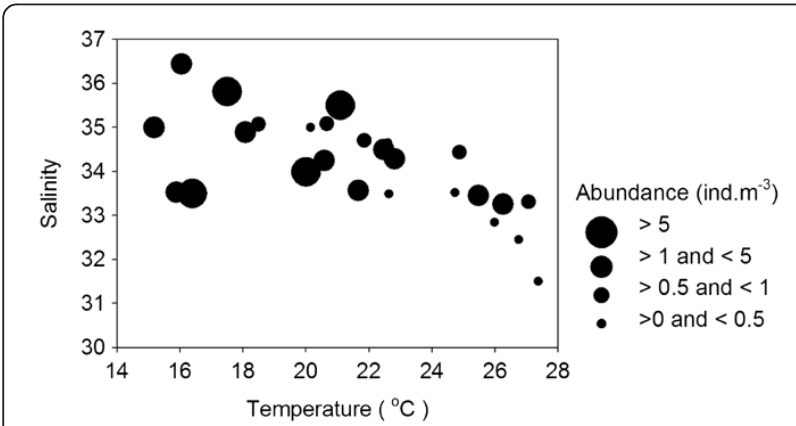

Figure 4 Relationship between the density of $P$. concinna and surface water temperature and salinity. Size of the circles represents the density range. females, stayed nearer to the surface than $P$. concinna females during both day and night, as shown by their WMDs (Table 1). Acrocalanus and Paracalanus/ Parvocalanus did not exhibit DVM, as both WMD and percentage of the population at the surface did not differ significantly between day and night $(p>0.05)$. The WMDs of Acrocalanus and Paracalanus/Parvocalanus differed significantly $(p<0.05)$ from that of $P$. concinna females only during the day. In contrast, the vertical distribution of Canthocalanus copepodites, which were not positively selected by $P$. concinna, overlapped with that of $P$. concinna. Their WMD appeared to be very similar to that of $P$. concinna females during both day and night (Table 1). Canthocalanus copepodites exhibited weak DVM, as significant diel difference was found only in the percentage of the population at the surface $(p<0.05)$, but not in WMD $(p>0.05)$.

\section{Discussion}

\section{$P$. concinna seasonal and spatial distribution}

P. concinna is the most abundant Euchaetidae in the study area, comprising more than $70 \%$ of the total Euchaetidae population (Wong unpublished data). It is one of the four species of Euchaetidae ( $P$. concinna, E. rimana, $P$. plana and E. indica) recorded in Hong Kong's coastal waters $[20,24,32,33]$. Along the Chinese coast, P. concinna has been reported from the East China Sea, the Taiwan Strait and the South China Sea 

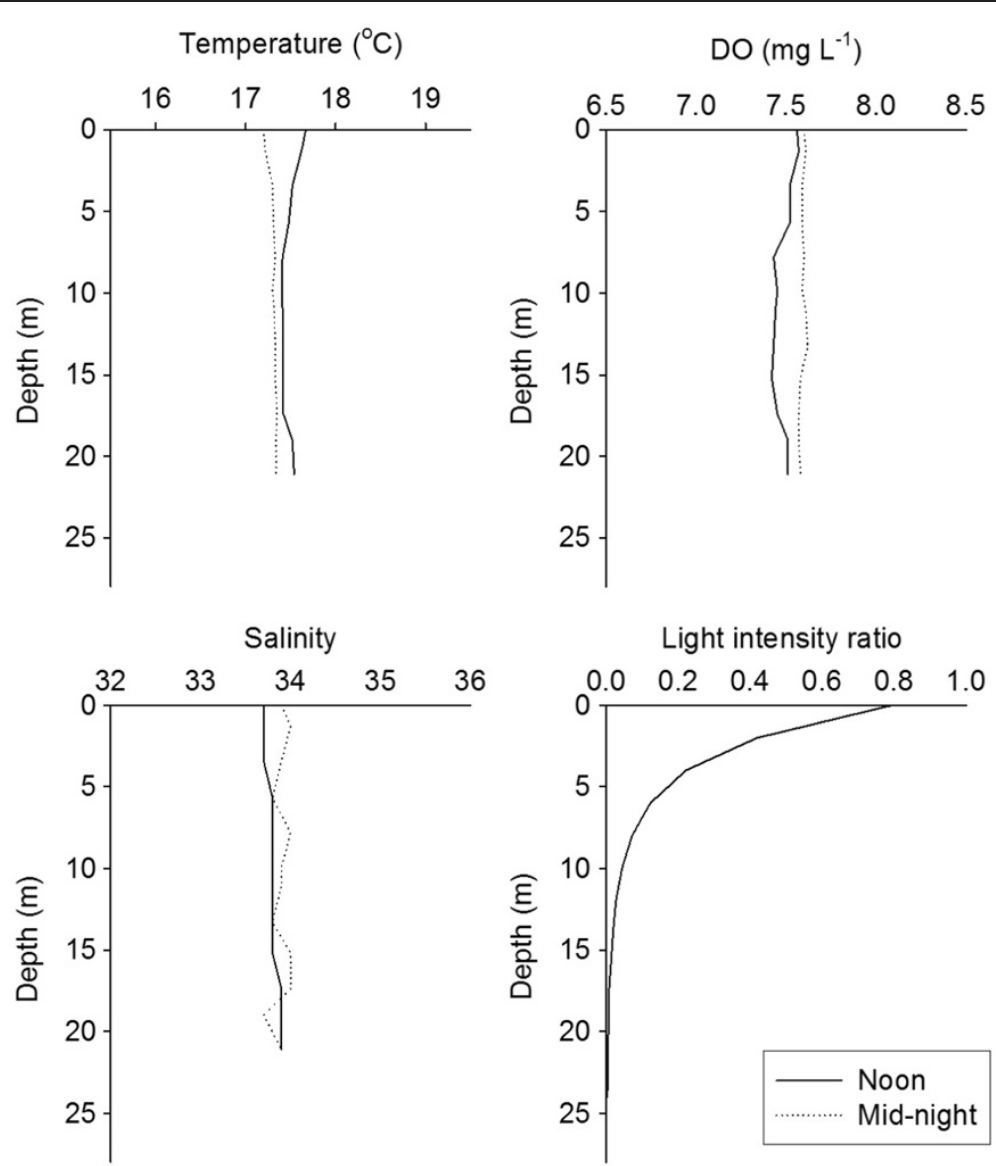

Figure 5 Vertical profiles of temperature, salinity, dissolved oxygen (DO), and light intensity ratio (noon only) at noon and midnight during the diel behavior study at S5 on 6-7 January 2005. "Light intensity ratio" refers to the ratio of light intensity in the water to light intensity just above the surface.

$[18,19,34]$. The species is considered to be limited to the Indo-Pacific in distribution [1].

Our results are in agreement with previous studies that dense populations of $P$. concinna appear only in winter and spring in Hong Kong [20,22,32,33], when the water temperature is low $\left(16-24^{\circ} \mathrm{C}\right)$. In comparison, Euchaetidae in the temperate oceans of the East China Sea and the Yellow Sea exhibits an opposite seasonal pattern. Both $P$. concinna and E. rimana are carried by the Kuroshio Current into the coastal areas of the

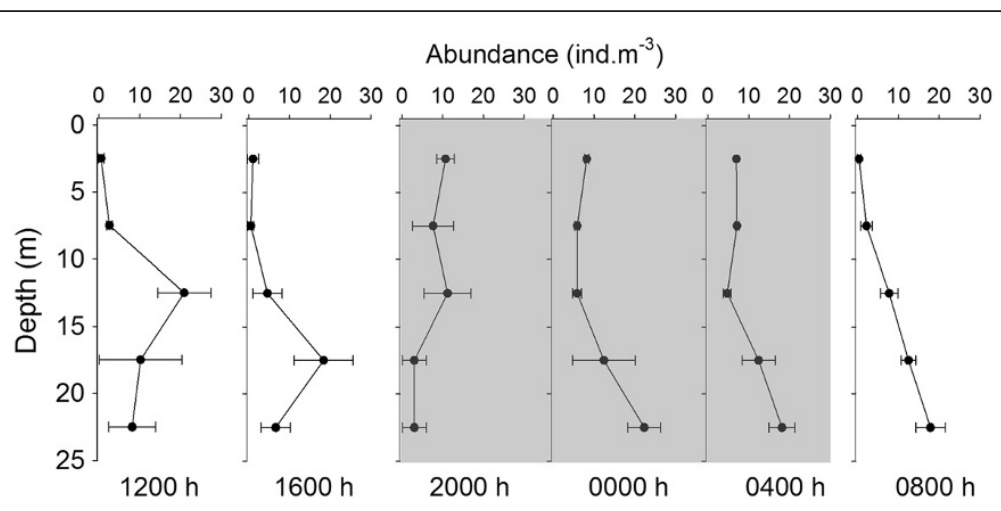

Figure 6 Diel variations in the mean density ( \pm Standard deviation) of female $P$. concinna at different layers of the water column. Grey shading represents nighttime. 
Table 1 Average values of weighted mean depth (WMD) and the percentage of the population at the surface during day and night for female (total, ovigerous, and non-ovigerous) and male $P$. concinna, Acrocalanus, Paracalanus and Parvocalanus, and Canthocalanus copepodites

\begin{tabular}{|c|c|c|c|c|c|c|}
\hline & \multicolumn{3}{|c|}{ WMD (m) } & \multicolumn{3}{|c|}{$\%$ of population at the surface $(0-5 \mathrm{~m})$} \\
\hline & Day & Night & $p$ & Day & Night & $p$ \\
\hline Female $P$. concinna & $16.8( \pm 1.3)$ & $12.8( \pm 3.1)$ & $<0.05$ & $6.1( \pm 2.8)$ & $38.3( \pm 12.1)$ & $<0.01$ \\
\hline Ovigerous & $17.2( \pm 1.9)$ & $12.9( \pm 3.2)$ & $<0.05$ & $4.1( \pm 5.6)$ & $37.3( \pm 14.5)$ & $<0.01$ \\
\hline Non-ovigerous & $16.9( \pm 1.4)$ & $13.3( \pm 3.1)$ & $<0.05$ & $6.1( \pm 7.4)$ & $33.4( \pm 9.6)$ & $<0.01$ \\
\hline Male $P$. concinna & $16.0( \pm 1.4)$ & $12.9( \pm 3.1)$ & $<0.05$ & $15.5( \pm 16.4)$ & $40.6( \pm 20.7)$ & $<0.05$ \\
\hline Acrocalanus & $9.8( \pm 3.4)$ & $10.5( \pm 2.9)$ & & $55.8( \pm 23.6)$ & $54.0( \pm 16.7)$ & \\
\hline Paracalanus and Parvocalanus & $9.9( \pm 1.1)$ & $10.3( \pm 7.2)$ & & $56.6( \pm 6.1)$ & $54.2( \pm 11.1)$ & \\
\hline Canthocalanus copepodites & $15.5( \pm 0.8)$ & $12.2( \pm 13.4)$ & & $21.8( \pm 7.6)$ & $41.2( \pm 11.5)$ & $<0.05$ \\
\hline
\end{tabular}

Student's t-test was used to test for the presence of diel vertical migration.

East China Sea, and reach peak densities in summer and autumn [18]. P. concinna occurs throughout the year in the northern Taiwan coast which is influenced by the Kuroshio Current year-round [35], but their density is higher in autumn and winter when water masses from the East China Sea flow toward Taiwan [35].

The abundance and distribution of copepods are known to be influenced by hydrographic conditions $[36,37]$. The density of $P$. concinna is lower in the semienclosed Tolo Harbour than the east and southeastern waters that are fully exposed to water currents from the South China Sea. The low densities at most times of the year, together with the pattern of shoreward decrease in density, suggest that $P$. concinna is transported into the coastal seas of eastern Hong Kong by water currents from the South China Sea, and the scarcity of $P$. concinna in the inner parts of Tolo Harbour can be explained by loss during physical transport.

On the other hand, trophic interactions may also influence the abundance of $P$. concinna in Tolo Harbour. The copepod community in Tolo Harbour is dominated by small copepods such as Parvocalanus crassirostris and Paracalanus parvus [26]. Such a plethora of small calanoid copepods suggests that carnivorous copepods such as $P$. concinna will not be limited by food [8,9,38,39]. Chang et al. [40] proposed that the density of large copepods, such as P. concinna, is controlled directly by fishes, while the density of small copepods is controlled by invertebrate predators. Several observations suggest that fish predation may contribute to the scarcity of large copepods such as $P$. concinna in Tolo Harbour and other nearshore areas of Mirs Bay. First, dense populations of the planktivorous Ambassis (glassfish) occur in Tolo Harbour throughout the year [41]. Secondly, copepods are known to be the major prey of larval and juvenile fishes which appear in large numbers in Tolo Harbour during late winter and early spring [42].

\section{Diel behaviors}

Both male and female P. concinna exhibit DVM. The congener Paraeuchaeta norvegica has been observed to perform DVM over depths of hundreds of meters [43$45]$, but there are also reports of non-migrating populations of this species $[12,16]$. The vertical distribution of P. norvegica [14] and Paraeuchaeta elongata [10,46] has been shown to be affected by ovigerity. The reproducing females of the calanoid copepod Eurytemora hirundoides have also been found to occupy deeper waters in the

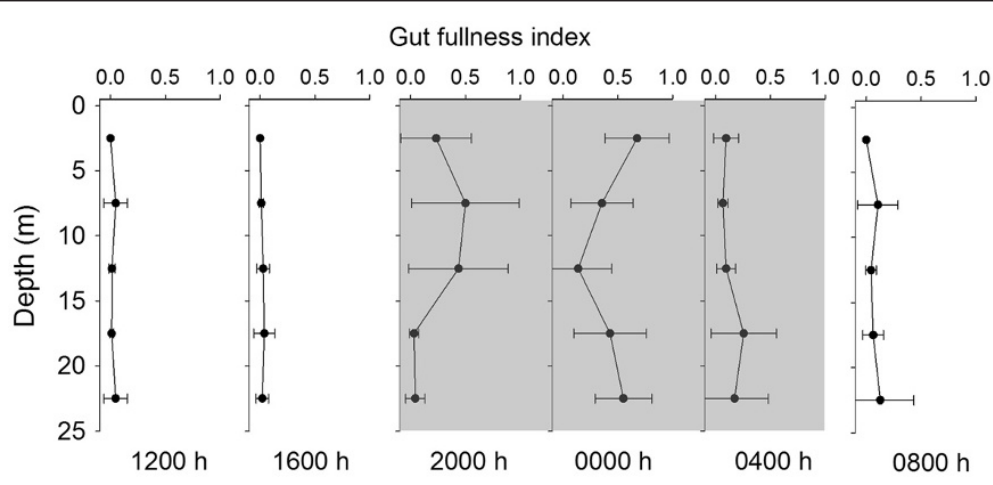

Figure 7 Diel variations in the gut fullness index ( \pm Standard deviation) of female $P$. concinna at different layers of the water column. Grey shading represents nighttime. $n=10$ for each data point. 


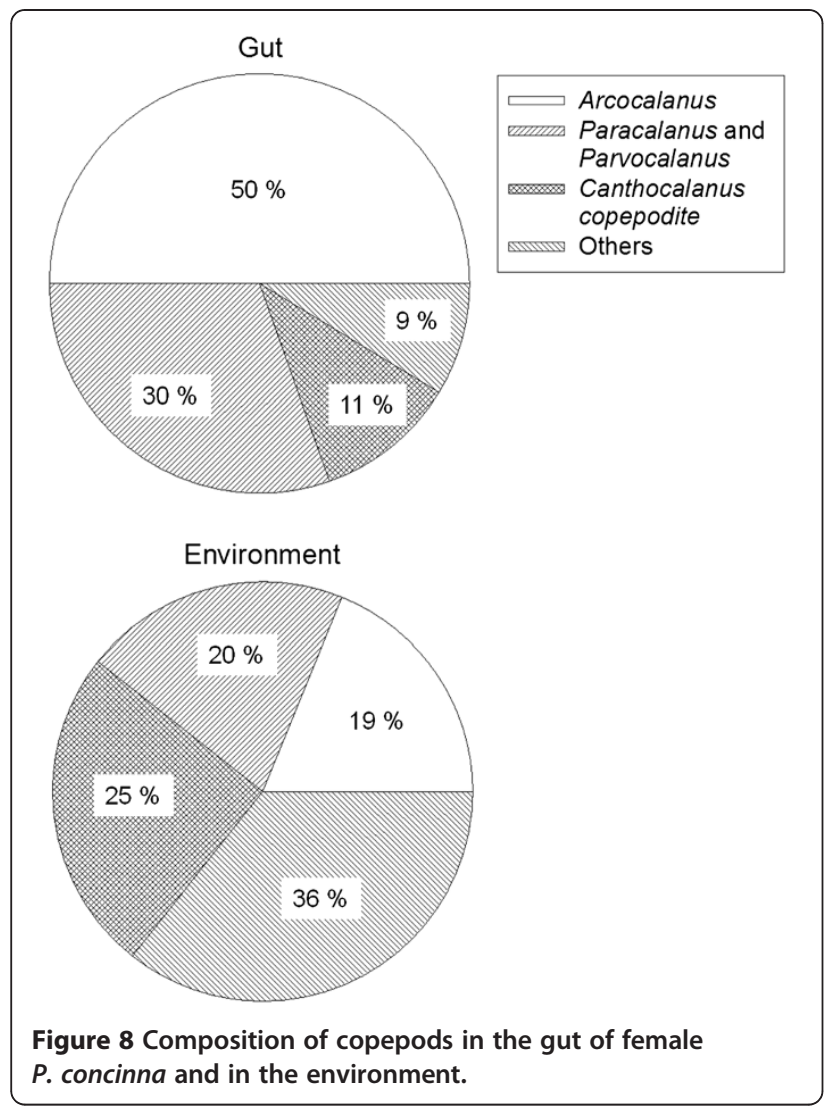

Archipelago Sea [47]. Ovigerous Eurytemora are highly selected by the planktivorous Baltic herring [48], and Vuorinen [49] has proposed that visual predation is the most probable cause of the difference in vertical distribution between ovigerous and non-ovigerous females. However, the results of this study show that both ovigerous and non-ovigerous females of $P$. concinna perform DVM.

DVM in crustacean zooplankton is widely considered to be an antipredator behavior [15,45,50-53]. Small pelagic organisms have no means to hide from visual predators, such as fish, in well-lit surface waters during the daytime, and must minimize predation risk by seeking refuge in deeper depths that have less light penetration [54]. Light is, therefore, commonly considered as a proximal cause or signal for zooplankton DVM $[55,56]$. Light intensity drops dramatically in the first $5 \mathrm{~m}$, and very little light penetrates into waters below $15 \mathrm{~m}$. The WMD of $P$. concinna is below $15 \mathrm{~m}$ during daytime. This suggests that $P$. concinna adjusts its vertical distribution to achieve an optimal balance between the energy cost of DVM and the benefit of reducing visual predation risks. Vuorinen [49] suggested that it may be a viable strategy for copepods to stay in deeper waters at all times if the temperature and food supply do not vary greatly between the deep and surface layers. While there was little temperature change with depth in the well-mixed, shallow waters of eastern Hong Kong, more than 50\% of the Acrocalanus and Paracalanus/Parvocalanus populations remained in the upper $0-5 \mathrm{~m}$ during both day and night, so the need for food may force $P$. concinna females to ascend to the surface at night. On the other hand, while adult male $P$. concinna do not feed, they still perform DVM and migrate to the surface at night. Such DVM behavior may therefore be an intrinsic behavior not driven by the need to feed, but other factors such as light. It is also possible that the P. concinna males follow the migrating females to increase the chance of mating, as male copepods of various species, e.g. Temora longicornis, Centropages typicus, Pseudocalanus elongatus, and Acartia tonsa, have been found to track and pursue female copepods through pheromones or hydromechanical signals for mating [57-59].

Diel patterns in gut fullness suggests that female $P$. concinna only feed actively at night. Diel feeding rhythms have been reported in Paraeuchaeta in both laboratory [39] and field studies [13,16]. Marked increase in the gut fullness of female P. concinna appears to coincide with their nocturnal ascent in the early part of the night, so the prevalence of individuals with relatively empty guts during the day may be due to a lack of access to prey. On the other hand, diel variations in gut fullness may not be associated with DVM. Female P. concinna stay in significantly deeper waters than Acrocalanus and Paracalanus/Parvocalanus during the day, but appear to share the same depths with Canthocalanus copepodites during both day and night. The absence of Canthocala$n u s$ in the guts of female $P$. concinna in daytime therefore suggests that the predators feed only at night, and implies that the diel variations in gut fullness was not the result of the predators migrating into and out of the prey-rich surface layer. Other studies have found that copepods exhibit diel variations in the gut contents regardless of whether they perform DVM. The gut fluorescence of both surface dwelling and migrating zooplankton in the Bedford Basin reaches peak values only at night [60]. Diel feeding rhythm in two species of Calanus in the Bering Sea is also independent of DVM [61], and though Calanus pacificus in Dabob Bay performs DVM and enters into the surface layer $2.5 \mathrm{~h}$ before sunset, its gut pigment content only increases substantially after sunset [62].

Diel feeding rhythm in zooplankton is often regarded as a strategy to avoid the accumulation of pigments in daytime [62,63], the purpose of which is to reduce the risk of attack by visual predators. Laboratory and field experiments with the rainbow trout Salmo gairdneri have confirmed that visual predators select the most pigmented calanoid copepods as prey [64]. Bollens and Stearns [65] reported that the gut fullness of Acartia hudsonica is lower in the presence than in the absence 
of fish. A. hudsonica and Acartia tonsa reduce their gut fullness in the presence of fish exudates, and the response is observed only when the light level is sufficient for visual predation [66]. These results suggest that $P$. concinna females may stop feeding during the day to reduce the chances of being attacked by fishes.

\section{Prey composition and selectivity}

Small calanoid copepods constitute $\sim 40 \%$ of the prey in the guts of female $P$. concinna. The estimate is considered to be conservative as some unidentified items found in the guts may also be the remains of calanoid copepods. The importance of calanoid copepods as food for female $P$. concinna is in accordance with previous findings on the natural diets of Paraeuchaeta species [9,38]. Copepods including Metridia gerlachei, Calanoides acutus, Euchaeta spp., Oncaea spp., and Oithona spp. made up $80-90 \%$ of the prey consumed by adults and copepodites (C5) of Paraeuchaeta antarctica in Antarctic waters [9]. Øresland and Ward [38] also reported that copepods form 46-99\% of the diets of P. antarctica, Paraeuchaeta farrani, Paraeuchaeta rasa, and Paraeuchaeta biloba in South Georgia.

$P$. concinna females feed on a variety of small calanoid copepods including Canthocalanus, Centropages, and Subeucalanus, but show strong preference for Acrocalanus, Parvocalanus, and Paracalanus. In laboratory feeding experiments, Yen [67] found that prey size is an important factor in the dietary selectivity of $P$. norvegica. The prosome length of preferred copepod prey is usually $\sim 70 \%$ the length of the second basipodal segment of the maxilliped of the predator. A similar proportion of $65 \%$ was found for $P$. antarctica, which exhibits the highest feeding rates on copepods with prosome length of $1.2 \mathrm{~mm}$ [8]. In this study, the prosome length of Acrocalanus $(\sim 0.6-0.7 \mathrm{~mm})$ is about $65-75 \%$ the length of the second basipodal segment of the maxilliped $(\sim 0.92 \mathrm{~mm})$ of $P$. concinna females, agreeing with the optimal prey size proposed by Yen [44]. On the other hand, the prosome lengths of Paracalanus and Parvocalanus $(\sim 0.3-0.4 \mathrm{~mm})$ are only $33-40 \%$ the length of the second basipodal segment of the maxilliped of $P$. concinna. These smaller copepods may therefore be more suitable prey for the smaller late copepodite stages of $P$. concinna ( $\mathrm{C} 4$ and $\mathrm{C5}$ ). The prosome length of the negatively selected Canthocalanus copepodites $(\sim 0.8-1.0 \mathrm{~mm})$ is $\sim 85 \%$ the length of the second basipodal segment of the predator maxilliped.

$P$. concinna females in this study did not feed on cyclopoid copepods, even though small cyclopoid copepods including Oithona and Oncaea were common in the gut of $P$. antarctica and may be the major prey of this predatory copepod, especially the copepodite stages $[9,38,68]$. Yen [67] reported that the cyclopoid copepods Oithona and Corycaeus are not preferred prey of $P$. antarctica, and proposed that the intermittent and darting movement of cyclopoid copepods are not easily detected by tactile predators. The copepod community in Mirs Bay is dominated by calanoid copepods (> 80\% of the total copepod population), and Oithona and Oncaea species only comprise $\sim 7 \%$ and $5 \%$ respectively of the total copepod populations [25]. The reason for the absence of cyclopoid copepods in the gut of female $P$. concinna may be a combination of the prey's low abundance, small size (prosome length $\sim 0.2-0.3 \mathrm{~mm}$ ), and less detectable swimming behavior.

\section{Digestion time and feeding rate}

Tönnesson et al. [6] found a gut evacuation rate of 0.080 $\mathrm{h}^{-1}$ or digestion time of $12 \mathrm{~h}$ at $15^{\circ} \mathrm{C}$ for $P$. norvegica. This is much longer than the digestion time of $\sim 5 \mathrm{~h}$ recorded at $18^{\circ} \mathrm{C}$ for $P$. concinna in this study. The relationship between the predator size and digestion time in copepods is unclear, although some studies have found no relationship between digestion time and predator size $[69,70]$. A common conclusion from previous studies is that digestion time varies with temperature [71-75] and prey size [76]. The higher water temperature in the subtropical seas of Hong Kong may allow shorter digestion times for female $P$. concinna, but it can also be argued that Paracalanus and Pseudocalanus, the copepod prey used to estimate the digestion time of $P$. norvegica [6], are bigger than Acrocalanus and Paracalanus/ Parvocalanus, the natural prey of $P$. concinna. On the contrary, Yen [77] reported a considerably higher gut evacuation rate of $0.43 \mathrm{~h}^{-1}$ and correspondingly very short digestion time of $\sim 2 \mathrm{~h}$ for $P$. norvegica feeding on cod larvae at $7.5^{\circ} \mathrm{C}$. As fish larvae lack the chitinous exoskeleton of copepod prey, they may be more easily digestible.

While the daily feeding rate of copepods changes with temperature and prey availability [35,71-73], our estimated daily feeding rates for female $P$. concinna feeding on Acrocalanus ( 4.7 prey predator ${ }^{-1} \mathrm{~d}^{-1}$ ) and Paracalanus/Parvocalanus ( 4.4 prey predator $\left.{ }^{-1} \mathrm{~d}^{-1}\right)$ are within the range of values reported for $P$. norvegica. Olsen et al. [78] reported a feeding rate of 3.6 prey predator $^{-1} \mathrm{~d}^{-1}$ at $7-10^{\circ} \mathrm{C}$ in the laboratory. Tönnesson et al. [6] reported in situ feeding rates of 1.4-5.2 prey predator $^{-1} \mathrm{~d}^{-1}$ at $5^{\circ} \mathrm{C}$ and $6.2-8.6$ prey predator ${ }^{-1} \mathrm{~d}^{-1}$ at $15^{\circ} \mathrm{C}$.

\section{Predation impact}

P. concinna females remove $\sim 4.3 \%$ of both the Acrocalanus and Paracalanus/Parvocalanus standing stock daily in the coastal sea of eastern Hong Kong. The estimates were conservative as only predation by adult females was considered. Øresland [9] found that the feeding rates of copepodites are higher than that of 
adults in Antarctic waters. The predation impact by the entire $P$. concinna population may therefore be higher as Paracalanus and Parvocalanus are small enough to be eaten by late copepodite stages, which are frequently more abundant than adults (Wong unpublished data). Predation impact estimated for female $P$. concinna in this study is within the range of values reported for other predatory copepods. Tönnesson et al. [6] reported a predation impact of $2.0-6.5 \%$ on small copepods by $P$. norvegica in the Skagerrak. The predation impact of Tortanus spp. on small copepod populations ranged from $1 \%$ in San Franscisco Estuary [79], to $2.7 \%$ in Fukuyama Harbour [80].

Copepods are also the major prey of chaetognaths. While the predation impact of chaetognaths on copepods can reach $6 \%$ in Northern Chile [81] and $7.8 \%$ in the eastern Mediterranean [82], a recent study conducted in Tolo Harbour and Mirs Bay showed that the predation impact of chaetognath on the copepod population is $<1 \%$ [83]. This finding suggests that $P$. concinna may play a more important role than other invertebrate predators in regulating the populations of small calanoid copepods in the eastern waters of Hong Kong, especially during winter and spring.

\section{Conclusions}

$P$. concinna is common in the coastal waters of eastern Hong Kong only during winter and spring. A trend of shoreward decrease in abundance suggests that the population in the shallow areas of eastern Hong Kong is derived from populations in offshore areas in the South China Sea. The entire adult population of $P$. concinna remains in dark, deeper waters during the day, probably to minimize the risks of fish predation. At night, $P$. concinna migrate to the surface, where their preferred prey, Acrocalanus, Paracalanus, and Parvocalanus stay throughout the day. P. concinna females with full guts are most common at night, but the diel feeding rhythm is probably not related to DVM. P. concinna removes $\sim 4.3 \%$ of the Acrocalanus, Paracalanus, and Parvocalanus standing stock daily, making it an important predator of small calanoid copepods.

\section{Abbreviations \\ DVM: Diel vertical migration; WMD: Weighted mean depth.}

\section{Competing interests}

The authors declare that they have no competing interests.

\section{Authors' contributions}

CKW was the Principal Investigator responsible for conceiving, coordinating, obtaining the funding to carry out the study, and modified the final draft of the manuscript. EYWY carried out the experimental work, prepared and analyzed the data, and wrote the first draft of the manuscript. AAYL analyzed and interpreted the data and results, and finalized the manuscript. All the authors read and approved the final manuscript.

\section{Acknowledgements}

The authors would like to thank Mr. Y.H. Yung, Mr. P. Tse, Mr. Y.K. Kwok, and Ms. V.C.Y. Li for assisting in acquisition of the samples, and Mr. K.C. Cheung for providing technical assistance.

Received: 3 May 2012 Accepted: 26 October 2012

Published: 5 November 2012

\section{References}

1. Park T: Taxonomy and distribution of the marine calanoid copepod family Euchaetidae, Bulletin of the Scripps Institution of Oceanography vol 29. San Diego: University of California Press; 1995.

2. Båmstedt U, Skjoldal HR: Studies on the deep-water pelagic community of Korsfjorden, western Norway. Adenosine phosphates and nucleic acids in Euchaeta norvegica (Copepoda) in relation to its life cycle. Sarsia 1976, 60:63-80.

3. Bakke LW: Ecological studies on the deep-water pelagic community of Korsfjorden, western Norway. Population dynamics of Euchaeta norvegica (Crustacea, Copepoda) from 1971 to 1974. Sarsia 1977, 63:49-55.

4. Bathmann UV, Noji $\Pi$, von Bodungen B: Copepod grazing potential in late winter in the Norwegian Sea - a factor in the control of spring phytoplankton growth? Mar Ecol Prog Ser 1990, 60:225-233.

5. Eiane K, Aksnes DL, Ohman MD, Wood S, Martinussen MB: Stage-specific mortality of Calanus spp. under different predation regimes. Limnol Oceanogr 2002, 47:636-645.

6. Tönnesson K, Nielsen TG, Tiselius P: Feeding and production of the carnivorous copepod Paraeuchaeta norvegica in the Skagerrak. Mar Ecol Prog Ser 2006, 314:213-225.

7. Ohman MD, Frost BW, Cohen EB: Reverse diel vertical migration: an escape from invertebrate predators. Science 1983, 220:1404-1407.

8. Yen J: Predatory feeding behaviour of an Antarctic marine copepod, Euchaeta antarctica. Polar Res 1991, 10:433-442.

9. Øresland V: Feeding of the carnivorous copepod Euchaeta antarctica in Antarctic waters. Mar Ecol Prog Ser 1991, 78:41-47.

10. Mauchline J: Bathymetric adaptations of life history patterns of congeneric species (Euchaeta: Calanoida) in a $2000 \mathrm{~m}$ water column. J Mar Sci 1995, 52:511-516.

11. Alonzo F, Mayzaud P, Razouls S: Egg production, population structure and biochemical composition of the subantarctic copepod Paraeuchaeta antarctica in the Kerguelen Archipelago. Mar Ecol Prog Ser 2000, 205:207-217.

12. Fleddum A, Kaartvedt S, Ellertsen B: Distribution and feeding of the carnivorous copepod Paraeuchaeta norvegica in habitats of shallow prey assemblages and midnight sun. Mar Biol 2001, 139:719-726.

13. Skarra $H$, Kaartvedt S: Vertical distribution and feeding of the carnivorous copepod Paraeuchaeta norvegica. Mar Ecol Prog Ser 2003, 249:215-222.

14. Vestheim H, Kaartvedt S, Edvardsen B: State-dependent vertical distribution of the carnivore copepod Paraeuchaeta norvegica. J Plankton Res 2005, 27:19-26.

15. Bollens SM, Frost BW: Zooplanktivorous fish and variable diel vertical migration in the marine planktonic copepod Calanus pacificus. Limnol Oceanogr 1989, 34:1073-1083.

16. Kaartvedt S, Dale T, Bagøien E, Viken T: Bi-model vertical distribution of the carnivorous copepod Paraeuchaeta norvegica. J Plankton Res 2002, 24:155-158.

17. Hays GC: A review of the adaptive significance and ecosystem consequences of zooplankton diel vertical migrations. Hydrobiologia 2003 503:163-170.

18. Chen QC, Zhang SZ: On planktonic copepods of the Yellow Sea and the East China Sea. I. Calanoida. Stud Mar Sin 1965, 7:20-131. In Chinese with English abstract.

19. Zheng Z, Zhang SZ: Marine pelagic copepods of China. Shanghai: Shanghai Science and Technology Press; 1985 (In Chinese).

20. Chen QC: The marine zooplankton in Hong Kong. In The marine flora and fauna of Hong Kong and southern China. Edited by Morton B, Tseng CK. Hong Kong: Hong Kong University Press; 1982:789-799.

21. Hwang JS, Chen QC, Wong CK: Taxonomic composition, density and biomass of free-living copepods in the coastal waters of southwestern Taiwan. Crustaceana 2003, 76:193-206. 
22. Lee CNW, Chen QC: A historical and biogeographical analysis of the marine planktonic copepod community in Hong Kong: a record of change. In Perspectives on marine environment change in Hong Kong and southern China, 1977-2001. Edited by Morton B. Hong Kong: Hong Kong University Press; 2003:433-457.

23. Yang $\mathrm{CL}$, Chang TS, Ming AL, Hung ZS: Spring distribution of copepods in relation to water masses in the northern Taiwan Strait. Zool Stud 2004 43:332-342.

24. Lee CNW: Seasonal changes in the planktonic copepod community of the southeastern coastal waters of Hong Kong. In Perspectives on marine environment change in Hong Kong and southern China, 1977-2001. Edited by Morton B. Hong Kong: Hong Kong University Press; 2003:367-387.

25. Zhang G, Wong CK: Changes in the planktonic copepod community in a landlocked bay in the subtropical coastal waters of Hong Kong during recovery from eutrophication. Hydrobiologia 2011, 666:277-288.

26. Wong CK, Chan ALC, Chen QC: Planktonic copepods of Tolo Harbour, Hong Kong. Crustaceana 1993, 64:76-84.

27. Worthington EB: Vertical movements of freshwater macroplankton. Int Rev Gesamten Hydrobiol 1931, 25:394-436.

28. Lee S: Preliminary studies on the food and feeding habits of some marine planktonic copepods in Amoy waters. J Xiamen Univ 1964, 11:93-109. In Chinese.

29. Yen J: Directionality and swimming speeds in predator-prey and malefemale interactions of Euchaeta rimana, a subtropical marine copepod. Bull Mar Sci 1988, 43:395-403.

30. Chesson J: Measuring preference in selective predation. Ecology 1978, 59:211-215.

31. Chesson J: The estimation and analysis of preference and its relationship to foraging models. Ecology 1983, 64:1297-1304.

32. Chen QC, Wong CK, Tam PF, Lee CNW, Yin JQ, Huang LM, Tam YH: Variations in the abundance and structure of the planktonic copepod community in the Pearl River Estuary, China. In Perspectives on marine environment change in Hong Kong and southern China, 1977-2001. Edited by Morton B. Hong Kong: Hong Kong University Press; 2003:389-400.

33. Chan ALC: The ecology of marine plankton in Tai Tam Bay, Hong Kong with special reference to barnacle (Arthropoda: Cirripedia) larvae, PhD Thesis. Hong Kong: The University of Hong Kong, Zoology Department; 1995.

34. Chen QC, Shen CJ: The pelagic copepods of the South China Sea II. Stud Mar Sin 1974, 9:125-137.

35. Yang GM, He DH, Wang CS, Miao YT, Yu HH: Study on the biological oceanographic characteristics of planktonic copepods in the waters north of Taiwan, China. I. Abundance distribution. Acta Oceanol Sin 1999, 21:78-86. In Chinese with English abstract.

36. Boucher M, Ibanez F, Prieru L: Daily and seasonal variation in the spatial distribution of zooplankton populations in relation to the physical structure in the Ligurian Sea Front. J Mar Res 1987, 45:133-173.

37. Shih CT, Chiu TS: Copepod diversity in the water masses of the southern East China Sea north of Taiwan. J Mar Syst 1998, 15:533-542.

38. Øresland V, Ward P: Summer and winter diet of four carnivorous copepod species around South Georgia. Mar Ecol Prog Ser 1993, 98:73-78.

39. Yen J: Sources of variability in attack rates of Euchaeta elongata Esterly, a carnivorous marine copepod. J Exp Mar Biol Ecol 1982, 63:105-117.

40. Chang $\mathrm{KH}$, Nagata T, Hanazato T: Direct and indirect impacts of predation by fish on the zooplankton community: an experimental analysis using tanks. Limnology 2004, 5:121-124.

41. Wong CK, Li VCY, Chan A: Diel cycles of reproduction and vertical migration in the marine cladocerans Pseudevadne tergestina and Penilia avirostris. J Plankton Res 2008, 30:65-73.

42. Nip HM, Ho WY, Wong CK: Feeding ecology of larval and juvenile black seabream (Acanthopagrus schlegeli) and Japanese seaperch (Lateolabrax japonicus) in Tolo Harbour, Hong Kong. Environ Biol Fish 2003, 66:197-209.

43. Longhurst AR, Williams R: Materials for plankton modeling: Vertical distribution of Atlantic zooplankton in summer. J Plankton Res 1979, 1:1-28.

44. Yen J: Vertical distribution and migratory activity of 3 species of Euchaeta, a carnivorous marine copepod. Bull Mar Sci 1985, 37:781-782.

45. Mauchline J: Restriction of body size spectra within species of deep-sea plankton. Mar Ecol Prog Ser 1992, 90:1-8.

46. Bollens SM, Frost BW: Diel vertical migration in zooplankton: rapid individual response to predators. J Plankton Res 1991, 13:1359-1365.
47. Vuorinen I, Rajasilta M, Salo J: Selective predation and habitat shift in a copepod species - support for the predation hypothesis. Oecologia 1983, 59:62-64.

48. Sandström O: Selective feeding by Baltic herring. Hydrobiologia 1980, 69:199-207.

49. Vuorinen I: Vertical migration of Eurytemora (Crustacea, Copepoda): a compromise between the risks of predation and decreased fecundity. J Plankton Res 1987, 9:1037-1046.

50. Zaret TM, Suffern JS: Vertical migration in zooplankton as a predator avoidance mechanism. Limnol Oceanogr 1976, 21:804-813.

51. Bollens SM, Frost BW: Ovigerity, selective predation, and variable diel vertical migration in Euchaeta elongata (Copepoda: Calanoida). Oecologia 1991, 87:155-161.

52. Bollens SM, Frost BW, Thoreson DS, Watts SJ: Diel vertical migration in zooplankton: field evidence in support of the predator avoidance hypothesis. Hydrobiologia 1992, 234:33-39.

53. De Robertis A, Jaffe JS, Ohman MD: Size-dependent visual predation risk and the timing of vertical migration in zooplankton. Limnol Oceanogr 2000, 45:1838-1844.

54. Lampert W: The adaptive significance of diel vertical migration of zooplankton. Funct Ecol 1989, 3:21-27.

55. Andersen $V$, Nival P: A model of the diel vertical migration of zooplankton based on euphausiids. J Plankton Res 1991, 49:153-175.

56. Pearre $S \mathrm{Jr}$ : Eat and run? The hunger/satiation hypothesis in vertical migration: history, evidence and consequences. Biol Rev 2003, 78:1-79.

57. Doall MH, Colin SP, Strickler JR, Yen J: Locating a mate in 3D: the case of Temora longicornis. Phil Trans R Soc Lond B 1998, 353:681-689.

58. Yen J, Weissburg MJ, Doall MH: The fluid physics of signal perception by mate-tracking copepods. Phil Trans R Soc Lond B 1998, 353:787-804.

59. Kiørboe T, Bagøien E: Motility patterns and mate encounter rates in planktonic copepods. Limnol Oceanogr 2005, 50:1999-2007.

60. Mackas D, Bohrer R: Fluorescence analysis of zooplankton gut contents and an investigation of diel feeding patterns. J Exp Mar Biol Ecol 1976, 25:77-85.

61. Ishii $\mathrm{H}$ : In situ feeding rhythms of herbivorous copepods, and the effect of starvation. Mar Biol 1990, 105:91-98.

62. Dagg MJ, Frost BW, Walser WE Jr: Copepod diel migration, feeding and vertical flux of phaeopigments. Limnol Oceanogr 1989, 34:1062-1071.

63. Kleppel GS, Willibanks L, Pieper RE: Diel variation in body carotenoid content and feeding activity in marine zooplankton assemblages. J Plankton Res 1985, 7:569-580.

64. Byron ER: The adaptive significance of calanoid copepod pigmentation: A comparative and experimental analysis. Ecology 1982, 63:1871-1886.

65. Bollens SM, Stearns DE: Predator-induced changes in the diel feeding cycle of a planktonic copepod. J Exp Mar Biol Ecol 1992, 156:179-186.

66. Cieri WD, Stearns DE: Reduction of grazing activity of two estuarine copepods in response to the exudates of a visual predator. Mar Ecol Prog Ser 1999, 177:157-163.

67. Yen J: Selective predation by the carnivorous marine copepodEuchaeta elongata: laboratory measurements of predation rate verified by field observations of temporal and spatial feeding patterns. Limnol Oceanogr 1985, 30:577-597.

68. Hopkins TL: Food web of an Antarctic midwater ecosystem. Mar Biol 1985, 89:197-212

69. Szyper JP: Feeding rate of the chaetognath Sagitta enflata in nature. Estuar Coast Mar Sci 1978, 7:567-575.

70. Sullivan BK: In situ feeding behaviour of Sagitta elegans and Eukrohnia hamata (Chaetognatha) in relation to the vertical distribution and abundance of prey at ocean station 'P'. Limnol Oceanogr 1980, 25:317-326.

71. Kiørboe T, Mohlenbery F, Nicolajsen $\mathrm{H}$ : Ingestion rate and gut clearance in the planktonic copepod Centropages hamatus (Lilljeborg) in relation to food concentration and temperature. Ophelia 1982, 21:181-194.

72. Dam HG, Peterson WT: The effect of temperature on the gut clearance rate constant of planktonic copepods. J Exp Mar Biol Ecol 1988, 123:1-14.

73. Wlodarczyk E, Durbin AG, Durbin EG: Effect of temperature on lower feeding thresholds, gut evacuation rate, and diel feeding behaviour in the copepod Acartia hudsonica. Mar Ecol Prog Ser 1992, 85:93-106.

74. Uye S, Yamamoto F: In situ feeding of the planktonic copepod Calanus sinicus in the Inland Sea of Japan, examined by the gut fluorescence method. Bull Plankton Soc Japan 1995, 42:123-139. 
75. Li C, Sun S, Wang R, Wang X: Feeding and respiration rates of a planktonic copepod (Calanus sinicus) oversummering in Yellow Sea cold bottom waters. Mar Biol 2004, 145:149-157.

76. Martinussen MB, Båmstedt U: Digestion rate in relation to temperature of two gelatinous planktonic predators. Sarsia 2001, 86:21-35.

77. Yen J: Predation by Euchaeta norvegica Boeck on eggs and larvae of the Atlantic cod Gadus morhua L. J Exp Mar Biol Ecol 1987, 112:283-296.

78. Olsen EM, Jørstad T, Kaartvedt S: The feeding strategies of two large marine copepods. J Plankton Res 2000, 22:1513-1528.

79. Hooff RC, Bollens SM: Functional response and potential predatory impact of Tortanus dextrilobatus, a carnivorous copepod recently introduced to the San Francisco Estuary. Mar Ecol Prog Ser 2004, 277:167-179.

80. Uye S, Kayano Y: Predatory feeding behaviour of Tortanus (Copepoda: Calanoida): life-stage differences and the predation impact on small planktonic crustaceans. J Crustacean Biol 1994, 14:473-483.

81. Giesecke R, González HE: Feeding of Sagitta enflata and vertical distribution of chaetognaths in relation to low oxygen concentrations. J Plankton Res 2004, 26:475-486.

82. Kehayias G: Quantitative aspects of feeding of chaetognaths in the eastern Mediterranean pelagic waters. J Mar Biol Assoc UK 2003, 83:559-569.

83. Lie AAY, Tse P, Wong CK: Diel vertical migration, feeding, and coexistence of three species of chaetognaths (Flaccisagitta enflata, Aidanosagitta delicata, and Aidanosagitta neglecta) in a shallow subtropical bay. J Plankton Res 2012, 34:670-684.

doi:10.1186/2046-9063-8-28

Cite this article as: Wong et al: The seasonal distribution, diel vertical distribution and feeding behavior of Paraeuchaeta concinna in the shallow subtropical coastal waters of eastern Hong Kong. Aquatic Biosystems 2012 8:28.

\section{Submit your next manuscript to BioMed Central and take full advantage of:}

- Convenient online submission

- Thorough peer review

- No space constraints or color figure charges

- Immediate publication on acceptance

- Inclusion in PubMed, CAS, Scopus and Google Scholar

- Research which is freely available for redistribution 